\title{
HUMANITARIAN CONCERNS AND DEPORTATION ORDERS UNDER THE IMMIGRATION ACT 2009: ARE INTERNATIONAL OBLIGATIONS ENOUGH PROTECTION FOR THE IMMIGRANT WITH MENTAL ILLNESS?
}

\author{
Timothy P Fadgen* and Guy Charlton*
}

\begin{abstract}
New Zealand has long prided itself as a champion for human rights within the international community. At the same time, local immigration laws have been tightened and long-standing recognition of the rights of migrants has been eroded. One sub-class of migrants, and the focus of this article, are migrants suffering from a mental illness. This article addresses the narrow question of rights accorded these individuals under the Immigration Act 2009 in light of New Zealand's longstanding international human rights obligations. The article questions the protection afforded an individual facing deportation under this Act in light of statutory changes that no longer require an immigration officer to issue a justification for issuing an order of deportation and argues, in light of this legislative change, that a "hard look" standard of review is required if the judiciary is to continue to have any meaningful role in ensuring executive compliance with international obligations.
\end{abstract}

\section{INTRODUCTION}

This article examines the new humanitarian appeals provisions enacted in the Immigration Act 2009 (new Act or 2009 Act) in light of New Zealand's international obligations and commitment to natural justice and human rights, as exemplified by the Human Rights Act 1993. While the 2009 Act

Timothy Fadgen is a PhD candidate in political studies at the University of Auckland and a lecturer at the Auckland University of Technology. He holds a JD from the University of Maine.

* Guy Charlton is an Associate Professor at City University of Hong Kong. He holds a PhD from the University of Auckland and a JD from the University of Wisconsin-Madison. 
specifically limits the efficacy of the Human Rights Act 1993 in s 392 et seq by noting that "immigration matters inherently involve different treatment on the basis of personal characteristics", it nevertheless observes that human rights considerations are endemic in the migrant context and cannot be ignored. The article argues that the removal of the five-prong humanitarian test found in ss 22 and 105 of the Immigration Act 1987 (the 1987 Act) reduces the scope of judicial review on immigration decisions and as well, lessens the impact of international law with the concomitant greater scope for executive discretion. This wide discretion in humanitarian appeals afforded by the new Act coupled with the low Wednesbury standard of review currently employed by the courts in immigration appeals could potentially contradict New Zealand's internal human rights commitments and international obligations when applied to potential deportees with mental illnesses and disabilities, as well as potentially other protected classes under the Human Rights Act 1993. Under the new Act, the availability or non-availability of requisite health care in a potential deportee's home country is not considered a factor in the determination of whether a person is suffering from "arbitrary deprivation of life or cruel treatment" under international law. ${ }^{1}$ While this exclusion may offend New Zealand's domestic humanitarian notions, when considering certain medical illnesses and conditions it completely excludes the consideration of whether an individual will be vulnerable to State or societal discrimination due to his or her mental health diagnosis or condition upon repatriation. We argue that where these mental health or disability discrimination issues are raised, particularly in situations in which the executive determination upholding a deportation order is a mere summary without the addition of a written justification or explanation of the determination with regard to New Zealand's international obligations (as now permitted under the new Act), the courts should adopt a higher "hard look" standard of review in these appeals. Such an approach was recently rejected by the High Court in Babulal v Chief Executive, Department of Labour. ${ }^{2}$ We will argue here that this recent decision improperly understood and considered the appropriate standard of review and the court's role in ensuring executive adherence to domestic and international human rights obligations in the migration context.

\section{IMMIGRATION POLICY AND LAW IN NEW ZEALAND}

New Zealand has rightly prided itself as being an advocate for human rights and humanitarian concerns abroad as well as solicitous of those rights within its domestic administrative and judicial decision-making. The Human Rights Act 1993, which seeks to protect those human rights "in general accordance with United Nations Covenants or Conventions on Human Rights", has been accorded "special status" by the courts. ${ }^{3}$ The Economist has ranked New Zealand as the fifth most

1 Immigration Act 2009, s 131(5)(b).

2 Babulal v Chief Executive, Department of Labour HC Auckland CIV-2011-404-1773, 29 September 2011.

3 Director of Human Rights Proceedings $v$ NZ Thoroughbred Racing Inc [2002] 3 NZLR 333 (CA) at 339 per Elias CJ. 
democratic State in its annual democracy index. ${ }^{4}$ This adherence to human rights and civil liberties is undergirded by statutory and common law protections such as the Human Rights Act 1993, judicial review of executive action, natural justice and international human rights conventions. The courts have previously held that these protections inform the executive actions of New Zealand statutory tribunals such as the Immigration and Protection Tribunal (IPT) and potentially any decision of a public nature. ${ }^{5}$ Regarding international treaties and covenants, New Zealand courts have held that international treaty obligations and principles of customary public international law impose extra-legal restraints. The courts will "strive to interpret legislation consistently with the treaty obligations of New Zealand", ${ }^{6}$ and this should occur "whether or not the legislation was enacted with the purpose of implementing the relevant text."7

As pointed out above however, human rights law and the concern for the individual rights and humanitarian needs of particular migrants fits uncomfortably with migration law, which is premised on State sovereign control of its membership and territory. Migration control is one of the few remaining areas where State executive authority can, under the guise of State sovereignty, enjoy almost unbridled power to favour individuals for entry into its territory and admission to the political community. ${ }^{8}$ The common law has recognised this broad power. As noted by Cooke J, "[i]mmigration is a subject linked with foreign policy [and] ... [i]n that sense it falls within a sphere where the Courts are very slow to intervene." 9 To be sure, attitudes towards migrants and treatment of migrants have emphasised the decreasing "moral significance" of borders ${ }^{10}$ and a more "rightsbased" approach to migration control mechanisms, but the nation State remains the primary repository and manager of migrant policy and law. International norms and institutions have had an effect, but domestic politics and liberal democratic norms as articulated within the domestic polity, have had the paramount impact on national migration control policy and law. ${ }^{11}$ As such, the

4 Economist Intelligence Unit "Democracy index 2010: Democracy in retreat" (2010) <www.graphics.eiu.com>.

5 Royal Australasian College of Surgeons v Phipps [1999] 3 NZLR 1 (CA); O'Leary v Health Funding Authority [2001] NZAR 717 (HC).

$6 \quad$ Puli'uvea v Removal Review Authority (1996) 14 FRNZ 322 (CA) at 331.

7 New Zealand Airline Pilots Association Inc v Attorney-General [1997] 3 NZLR 269 (CA) at 289.

8 Catherine Dauvergne Making People Illegal: What Globalization Means for Migration and Law (Cambridge University Press, Cambridge, 2008). For a discussion of the impact globalisation has had on immigration and nationality policy see Stephen Legomsky "The Last Bastions of State Sovereignty: Immigration and Nationality go Global" in Andrew Sobel (ed) Challenges of Globalization: Immigration, Social Welfare, Global Governance (Routledge, New York, 2009) 43.

9 Ashby v Minister of Immigration [1981] 1 NZLR 222 (CA) at 226 per Cooke J.

10 David Held "Law of States, Law of Peoples: Three Models of Sovereignty" (2002) 8 LEG 1 at 20.

11 Virginie Guiraudon and Gallya Lahav "A Reappraisal of the State Sovereignty Debate: The case of Migration Control" (2000) 33 Comp Pol Stud 163 at 164. 
decisional efficacy of humanitarian considerations on administrative and judicial decision-making, while informed by international law, generally remains wedded to domestic conceptions of what is "humanitarian". Migration control in New Zealand, while joining the general liberalising trend, remains inherently discriminatory based on domestic law and norms related to considerations of sovereignty and on legal, economic and social policies outlining what constitutes a "desirable" migration policy. This manner of discrimination leaves little space for poor or uneducated migrants looking for economic opportunities similar to the immigrants who settled New Zealand over the past 150 years. Rather, it seeks to encourage a range of healthy migrants with sufficient wealth, economic potential or specialised knowledge to assist the national economy.

New Zealand, settled by a predominately British population, developed a migration policy dominated by economic, and to a lesser extent racial and social, considerations. After World War II the Government accepted the recommendation of the Dominion Population Commission that immigration (including government sponsored immigration from the United Kingdom and Northern Europe) could be used to fill jobs in secondary and tertiary industries that could not be staffed by the current workforce. ${ }^{12}$ In 1960 additional changes in the policy were made to staff essential industries. The economic arguments in favour of increased immigration often clashed with the widely subscribed notion that New Zealand wished to remain "British" and "non-Asian". ${ }^{13}$ From 1920 onward this policy provided that all individuals who were not "of British birth or parentage" were required to have an "entry permit." ${ }^{14}$ Under the system permits were difficult to attain for nonBritish Europeans but were "virtually unattainable by non-Europeans" except in the uncommon instance where the Minister decreed that a certain number be issued. ${ }^{15}$ Where there were exceptions to the non-European policy it was usually in favour of Pacific Islanders, the great majority of whom came from New Zealand-controlled territories. This racially discriminatory system was reaffirmed in the Immigration Act of $1964 .{ }^{16}$ The racial bias in the migration law did not escape notice from other States and was increasingly viewed by the public as antithetical to New Zealand's international obligations and liberal values. In 1987 the Government eliminated the last official vestiges of its implicit "White New Zealand" immigration policy by removing the preferences given to "traditional source countries" such as Great Britain, Northern Europe and North America. Today immigration policy is divided into three main categories: economic migrants (those individuals who have certain

12 Dominion Population Committee "Report of the Dominion Population Committee" [1946] AJHR I17 at 2122.

13 Malcolm McKinnon Immigrants and Citizens: New Zealanders and Asian Immigration in Historical Context (Institute of Policy Studies, Wellington, 1996) at 36-43.

14 Sean Brawley "No 'White Policy' in NZ: Fact and Fiction in New Zealand's Asian Immigration Record, 1946-1978" (1993) 27 NZJH 16 at 19.

15 Ibid.

16 Kerry Burke "Review of Immigration Policy, August 1986" [1986] AJHR G42. 
skills, occupations, entrepreneurial or business capacities), migrants who are admitted under family reunification rules and those admitted on humanitarian grounds. Along with these ostensibly economic or implicitly racialist policy aims, New Zealand has sought to balance social and financial considerations with the material needs of a settler economy looking to entice potential immigrants to resettle. Those individuals who suffered from mental illness or intellectual disabilities were considered undesirable and/or a burden on public finances. As early as 1846 , an Ordinance made provision for the safe custody and prevention of offences by "lunatics". ${ }^{17}$ Subsequently in 1873 , 1875, 1879 and 1882 Imbecile Passengers Act(s) and amendments were enacted requiring a bond for any passenger having a disability, including mental illness, to be held to defray any costs of care for the individual should they require public or private charitable care within five years of arrival. The Immigration Act 1964 prohibited any "mentally defective person" from landing as an immigrant in New Zealand and required a bond to be given for "mentally defective" passengers who were likely to become "a charge upon the public or upon any public or charitable institution". ${ }^{18}$ These policies - presuming that mentally ill or defective individuals are undesirable, or create an unwanted demand upon the public finances - continue to inform current migration processes.

While domestic considerations remain paramount in migration policies and law, international norms and obligations have been increasingly influential since World War II. As mentioned above New Zealand generally restricted entry to persons of British or Irish parentage prior to World War II, but after the War international norms concerning the plight of displaced persons and refugees (due to the egregious human rights violations occurring during the fighting and the Holocaust) became increasingly salient. Humanitarian considerations started to be considered alongside economic and country of origin criteria. ${ }^{19}$ Initially, these humanitarian considerations focused on refugees displaced by the conflict in Europe. After the War, the Government accepted 4,582 displaced European refugees as well as displaced persons who arrived on International Refugee Organisation ships. In 1956 it agreed to a quota of 1,000 (later increased to 1,300) Hungarian refugees following the aborted anti-communist revolution there and in 1958 New Zealand became one of the first countries to accept refugee families with "handicapped" (including ill health, disability, advanced age or large numbers of children) members. ${ }^{20}$ Section 40 of the Immigration Act 1964 reinforced the growing humanitarian element in migration decisions in statute when it stated: "Nothing in this Act shall affect the prerogative of mercy." This led to the practice where

17 Lunatics Ordinance 184610 Vict 21

18 Sections 4(1)(a) and 24.

19 Youcef Bouandel Human Rights and Comparative Politics (Dartmouth Publishing Company, Brookfield (Vermont), 1997); Thomas Buergenthal "The Normative and Institutional Evolution of International Human Rights" (1997) 19 Hum Rts Q 703.

20 New Zealand Parliament "Immigration chronology: selected events 1840-2008" (14 April 2008) Parliamentary support: Research papers <www.parliament.nz>. 
individuals who were subject to deportation would petition the Governor-General for a pardon, removing the underlying conviction that led to the deportation order. ${ }^{21}$ As part of this general move toward including international law in migration decisions, New Zealand ratified the Convention relating to the Status of Refugees in 1960, the International Convention on the Elimination of All Forms of Racial Discrimination in 1972, the International Covenant on Economic, Social and Cultural Rights (ICESCR) in 1978 and the United Nations Convention on the Rights of the Child (UNCROC) in 1993. ${ }^{22}$ These international obligations extended human rights and nondiscriminatory protections to those seeking to enter the country when they had a well-founded fear of persecution, and provided that the appropriate due process and humanitarian considerations be accorded individuals in gaining access to, or when being removed from New Zealand, regardless of the applicants' irremediable characteristics.

These international obligations are embedded in the Immigration Act 2009. The Act specifically incorporates New Zealand's international obligations under the United Nations Convention against Torture and other Cruel, Inhuman or Degrading Treatment or Punishment (CAT) and the International Covenant on Civil and Political Rights (ICCPR); which now includes the category of "protected person" alongside "refugee" (ss 129-131) in the determination of deportation liability. The international legal instruments include protections for those individuals who can establish "substantial grounds for believing that [they] would be in danger of being subjected to arbitrary deprivation of life or cruel treatment if deported from New Zealand". ${ }^{23}$ Consideration of both the substantive and procedural requirements of these instruments is mandatory when determining the validity of a migrant's claims to be a refugee or a protected person as well as in the deportation of such persons (s 164). Where an individual can demonstrate personal circumstances covered by "relevant" international obligations, s 177 of the Act allows a deportation order to be quashed.

As international law was being reconceptualised from a body concerned with the rights of States inter se to one where individuals are recognised as having certain rights, there were parallel domestic developments in the law regarding the rights of immigrants and aliens. Prior to 1980 "aliens" had no right to be in the country except by approval of the Crown; there were few if any

21 KJ Keith "Administrative Law Developments in New Zealand as seen through Immigration Law" in Grant Huscroft and Michael Taggart (eds) Inside and Outside Canadian Administrative Law: Essays in Honour of David Mullan (University of Toronto Press, Toronto, 2006) 125 at 128.

22 Convention relating to the Status of Refugees 189 UNTS 137 (opened for signature 28 July 1951, entered into force 22 April 1954); International Convention on the Elimination of All Forms of Racial Discrimination 660 UNTS 195 (opened for signature 21 December 1965, entered into force 4 January 1969); International Covenant on Economic, Social and Cultural Rights 993 UNTS 3 (opened for signature 19 December 1966, entered into force 3 January 1976) [ICESCR]; United Nations Convention on the Rights of the Child 1577 UNTS 3 (opened for signature 20 November 1989, entered into force 2 September 1990) [UNCROC].

23 Immigration Act 2009, s 131(1). 
protections for revocations of permits and immediate removal for aliens who did not have permission to be in the country. For example, the Court in Pagliara v Attorney-General, which considered the issue of whether an alien who had been convicted of a crime would be entitled to a hearing concerning his deportation, noted (quoting Lord Denning): ${ }^{24}$

But in the case of aliens, it is rather different; for they have no right to be here except by licence of the

Crown. And it has been held that the Home Secretary is not bound to hear representations on their

behalf, even in the case of a deportation order, though, in practice, he usually does so.

After 1980 the courts gradually extended procedural protections to migrants. In Daganayasi $v$ Minister of Immigration the Court held that a decision by the Minister to deport Daganayasi was invalid because the Minister had not allowed the appellant a chance to see or respond to a medical report which created an incorrect impression that there would be little risk of peril to the appellant's child should he be forced to leave New Zealand with his parents. ${ }^{25}$ This case signalled a fundamental shift in attitudes towards migrants. The general trend toward greater procedural protections was encouraged by s 27(1)(a) of the Bill of Rights Act 1990, which affirms the right of every person "to the observance of the principles of natural justice" in any administrative decision. The section was extended to the migration context when the Crown accepted that the s 27 natural justice provisions applied in Attorney-General v Udompun. ${ }^{26}$ Subsequently the Court of Appeal extended the procedural rights accorded to potential deportees' citizen children who would be affected by a deportation order. ${ }^{27}$ These considerations include addressing the fact that a citizen child's different status in his or her parents' home country may adversely impact or subject them to discrimination. ${ }^{28}$

\section{DEPORTATION, HUMANITARIAN APPEALS AND INTERNATIONAL OBLIGATIONS UNDER THE IMMIGRATION ACT 2009}

Deportation refers to "the act of a State in ... removing a non-national from its territory ... after refusal of admission or termination of permission to remain". ${ }^{29}$ Deportation orders are issued under Part 6 of the Immigration Act 2009 by the Minister of Immigration or Governor-General when a

24 Pagliara v Attorney-General [1974] 1 NZLR 86 (SC) at 94 quoting Schmidt v Secretary of State [1969] 1 All ER 904 (CA) at 908-909.

25 Daganayasi v Minister of Immigration [1980] 2 NZLR 130 (CA).

26 Attorney-General v Udompun [2005] 3 NZLR 204 (CA).

27 Ye v Minister of Immigration [2008] NZCA 291, [2009] 2 NZLR 596; Huang v Minister of Immigration [2008] NZCA 377, [2009] 2 NZLR 700.

28 Ye v Minister of Immigration [2009] NZSC 76, [2010] 1 NZLR 104 at [60]-[61].

29 Richard Perruchoud and Jillyanne Redpath-Cross "Glossary on Migration (2nd ed)" (2011) International Organization for Migration <www.iom.int> at 27. 
non-citizen threatens national security or is convicted of certain criminal offences. The deportation provisions were designed in light of the Act's overall objective to "better balance efficiency with fairness" 30 in immigration matters and to "manage immigration in a way that balances the national interest, as determined by the Crown, and the rights of individuals", ${ }^{31}$ while "implementing specified-related international obligations". ${ }^{32}$

Certain individuals who have been found liable for deportation may appeal to the Immigration Protection Tribunal (IPT) on a question of fact under s 201 or may file a humanitarian appeal under s 206. A person must file a humanitarian claim within the relevant time period specified by the Act, (which depends upon the liable deportee's immigration status) and may not file an appeal where the individual has already "had a humanitarian appeal heard by the Tribunal in relation to a claim or a subsequent claim". ${ }^{33}$ The grounds used by the IPT to evaluate a humanitarian appeal are set out in s 207 of the Act. The appeal must be allowed and the deportation order quashed if the IPT is satisfied that "there are exceptional circumstances of a humanitarian nature that would make it unjust or unduly harsh" for the appellant to be deported from New Zealand and "it would not in all the circumstances be contrary to the public interest to allow" the individual to remain in New Zealand. ${ }^{34}$ The appellant, while not carrying the burden of proof, has the responsibility to place material before the IPT which if accepted would allow the order to be quashed. ${ }^{35}$

Doug Tennent has noted that the s 207 "unjust or unduly harsh" balancing test was the "highest of all thresholds" used in humanitarian appeals under the Immigration Act 1987, and it is clear that the test is a high bar to a successful humanitarian appeal. ${ }^{36}$ Generally, the "unjust" portion of the test refers to the unfairness and the negative impact the requirement to leave would have on the person given the time the person has spent in New Zealand and the commitment the individual (work, social intercourse, wealth generation activities) has shown to the country. The "unduly harsh" aspect of the test refers to the impact deportation would have on family members and on those to whom the liable deportees are emotionally close. The determination of these factual issues is complicated by several additional factors. First, precisely what qualifies as a "humanitarian" ground is not defined in the Act nor fully elucidated in case law. It is clear that the suffering and dangers to life which led to the enactment of the Convention relating to the Status of Refugees, and the CAT, are

30 Immigration New Zealand "Immigration Act 2009: Summary of Key Changes" (December 2010) <www.immigration.govt.nz>.

31 Immigration Act 2009, s 3.

32 Immigration New Zealand, above n 30.

33 Immigration Act 2009, s 206(3)(b).

34 Ibid, s 207.

35 Faavae v Minister of Immigration [2000] NZAR 177 (CA).

36 Douglas Tennent Immigration and Refugee Law (LexisNexis, Wellington, 2010) at 290. 
"humanitarian" issues, as are such circumstances as the effects of family separation for families and children who have some members who have the right to stay in New Zealand. In addition, circumstances such as the existence of physical or mental infirmity, mental illness, or where a person would be prejudiced or otherwise adversely affected by his or her race, ethnic origin, religion, nationality, sex or other status, or for their political opinions, or for an offence of a political character, may be considered. ${ }^{37}$ These factors are not in themselves determinative but the material nature of a "humanitarian" factor in the test is dependent upon the individual circumstances and the context. ${ }^{38}$ However, where the impact on a potential deportee goes beyond the relatively narrow compass of a "well-founded" fear of physical harm or persecution, the humanitarian nature of a particular factor or status within a particular context is difficult to ascertain, and can often be an issue of semantics rather than legal standard or principle. For example, while it is clear that the impact of deportation and the personal and family life of a child is a humanitarian issue and, according to the UNCROC, one which should be a "primary" consideration, the courts have read down the Convention in the immigration context. As noted by Tipping $\mathrm{J}$ in Ye v Minister of Immigration: ${ }^{39}$

\footnotetext{
Article 3(1) [of the United Nations Convention on the Rights of the Child] provides that in all actions concerning children, by public and administrative authorities, the best interests of the child shall be "a primary consideration". A primary consideration does not mean the primary consideration, much less the paramount consideration. There is no basis for reading in, as the appellants argued, the Care of Children Act 2004 standard of "first and paramount consideration". That would not be consistent with the policy objectives which must be reconciled in cases of the present kind. ... The Care of Children Act is not concerned with immigration matters in respect of which the Immigration Act states the relevant policies.
}

Second, these humanitarian grounds must be of an "exceptional" nature. As such, the usual impacts of physical and mental health, and those suffered by families who have members who are subject to deportation cannot be humanitarian "concerns" which the test may consider to allow for a successful appeal. As the Supreme Court has observed: 40

The need for the circumstances of the case to be exceptional means that those circumstances must be well outside the normal run of circumstances found in overstayer cases generally. The circumstances do not have to be unique or very rare but they do have to be truly an exception rather than the rule.

37 Bujak v The Minister of Justice [2009] NZCA 570.

38 Minister of Immigration v Al-Hosan [2008] NZCA 462, [2009] NZAR 259.

39 Ye v Minister of Immigration, above n 28, at [24] per Tipping J. See also Puli'uvea v Removal Review Authority, above $\mathrm{n} 6$.

40 Ye v Minister of Immigration, above n 28, at [34] (footnote omitted). 
The high and relatively amorphous standard under s 207 of the Immigration Act 2009 is a significant change from the 1987 Act. In addition to the "unjust or unduly harsh" evaluation, the 1987 Act outlined a set of criteria to assist the appeal Tribunal and the courts in determining the quality and scope of the humanitarian concerns of the deportee. Sections 22 and 105 of the Immigration Act 1987, while using the same "unjust or unduly harsh" test carried over into the 2009 Act, mandated that the Tribunal have specific regard to several factors. ${ }^{41}$ These factors did not preclude the Tribunal from considering other factors but gave a structure to the inquiry while setting a minimum standard for judicial review. ${ }^{42}$ Hence, in place of the five-prong requirements of inquiry under the Immigration Act 1987, the 2009 Act merely requires a balance of the individual interest (exceptional humanitarian concerns resulting in an injustice or unduly harsh outcome beyond mere repatriation but not to the level of those faced by a refugee or protected person) and the community's interest, to permit the individual's continued presence in New Zealand. The community interest can be understood as the public interest in the deportation of the individual given the seriousness of the conviction and the likelihood of reoffending (for example, issues of social cohesion, public confidence, deterrence and repugnance of the public to the particular offence).

Despite the narrow scope necessitated by s 207 in the humanitarian appeal and the deportation process, there are international obligations which can inform both the admission and removal of individuals in the appeals process under the Act. The Act specifically incorporates New Zealand's international obligations under both the CAT and the ICCPR while enacting the international law category of "protected person" alongside the previously enacted category of "refugee". In addition, the Act consistently makes reference to "international obligations" which should be considered by immigration officials when making determinations on deportation orders.

41 Including:

(a) the appellant's age;

(b) the length of the period during which the appellant has been in New Zealand lawfully;

(c) the appellant's personal and domestic circumstances;

(d) the appellant's work record;

(e) the nature of the offence or offences of which the appellant has been convicted and from which the liability for deportation arose;

(f) the nature of any other offences of which the appellant has been convicted;

(g) the interests of the appellant's family; and

(h) such other matters as the Tribunal considers relevant (see s 2).

42 Al-Hosan v Deportation Review Tribunal HC Auckland CIV 2006-404-3923, 3 May 2007; Minister of Immigration v Al-Hosan, above n 38. 
Section 177, which allows for a deportation order to be quashed, specifically mentions "international obligations". Under the section, an immigration officer may cancel a deportation order at his or her "absolute discretion" where a "person provides information to the officer concerning his or her personal circumstances" and "the information is relevant to New Zealand's international obligations". ${ }^{43}$ While there is no right of appeal under this section, nor is the officer required to act on any information offered, the officer must, if exercising his or her discretion to cancel under s 177, "have regard to any [relevant] international obligations" under s 177(5), whether the consideration is at the prospective deportee's behest or not. The officer is not bound to issue any written justification for a decision under s 177(4)(a) but is "obliged to record ... a description of the international obligations; and ... the facts about the person's personal circumstances" wherever the officer has "regard to any international obligations" under ss 177(5)(a)-(b). Presumably, the record or summation made at this juncture is carried forward in any later appeal of the deportation order. It does however raise the spectre of more informed or knowledgeable officers taking a more proactive approach in applying "international obligations" to individuals presenting relevant grounds for official consideration.

In addition to the explicit international obligations mentioned in the Act, the courts have in certain instances read in other international obligations created by the Government. First, the courts, where not explicitly precluded from doing so, "should strive to interpret legislation consistently with the treaty obligations of New Zealand." 44 Second, where the treaty obligation has not yet been incorporated into statute but where the principles and rules reflect fundamental common law values and the rights outlined in the Bill of Rights Act 1990 (NZBORA) the courts will apply a presumption of consistency. ${ }^{45}$ In Zaoui v Attorney-General (No 2) the Supreme Court held that the presumption of consistency in favour of international obligations provided for certain substantive and procedural requirements within the context of the Immigration Act 1987. ${ }^{46}$ The extent to which courts are to include international norms or interpret statutes consistently with international obligations - particularly those international obligations which have not been directly incorporated into domestic law - remains largely unresolved. However, the issue highlights the differential

43 Immigration Act 2009, ss 177(1) and 177 (2).

44 Puli'uvea v Removal Review Authority, above n 6. See also Puli'uvea v Removal Review Authority [1996] 3 NZLR 538 (CA) at 542.

45 Michael Taggart "Rugby, the Anti-apartheid Movement, and Administrative Law" in Rick Bigwood (ed) Public Interest Litigation: The New Zealand Experience in International Perspective (LexisNexis, Wellington, 2006) 69 at 82.

46 Zaoui v Attorney-General (No 2) [2005] 1 NZLR 577 (SC). 
impacts of diverse interpretive approaches where courts are seeking to reasonably balance the protected rights in light of subsequent statutory language infringing upon those rights. ${ }^{47}$

\section{JUDICIAL REVIEW AND THE IMMIGRATION ACT 2009: BABULAL V CHIEF EXECUTIVE, DEPARTMENT OF LABOUR $^{48}$}

After a determination of deportation liability there may be an appeal to the courts. The review authority in immigration cases exists regardless of the extent of the discretionary power the executive exercises in a particular decision. There are two types of review: an appeal on a point of law and judicial review. An appeal on a point of law argues that the substantive and procedural law relating to the case have been incorrectly interpreted or applied. Judicial review concerns whether the decision has been reached in a manner that is in accordance with the law in a fair and reasonable manner. ${ }^{49}$

Prior to the passage of the 2009 Act the scope of review was limited. However the incorporation of international obligations, the congruence of many substantive and procedural rights claimed in migration proceedings with fundamental common law rights, and rights guaranteed by the NZBORA, had seemingly pushed the courts to observe a more assertive stance and more exacting

47 Claudia Geiringer "Tavita and All That: Confronting the Confusion Surrounding Unincorporated Treaties and Administrative Law" (2004) 21 NZULR 66.

48 Babulal v Chief Executive, Department of Labour, above n 2.

49 Wolf $v$ Minister of Immigration (2004) HRNZ 469 (HC); Tennent, above n 36, at 296. "A hard-look approach or heightened level of intensity of review is appropriate, but even on a Wednesbury analysis the immigration officer acted unreasonably and irrationally": Bugdaycay v Secretary of State for the Home Department [1987] 1 AC 514 (HL) at 531 per Bridge LJ; R (Mahmood) v Secretary of State for the Home Department [2001] 1 WLR 840 (CA) at [18]; Pharmaceutical Management Agency Ltd v Roussel Uclaf Australia Pty Ltd [1998] NZAR 58 (CA) at 66; Discount Brands Ltd v Westfield (New Zealand) Ltd [2005] NZSC 17, [2005] 2 NZLR 597 at [54] per Keith J and [116] per Blanchard J (with Richardson J agreeing at [179]; $R$ (Daly) v Secretary of State for the Home Department [2001] 2 AC 532; and $R v$ Ministry of Defence, ex $p$ Smith [1996] QB 517 (CA) at 554 per Thomas Bingham MR. The level of intensity depends upon the nature of the right being interfered with: the more fundamental the right the higher the intensity of review. The right at issue here is the right of a child to be looked after by its natural parents, which is an important right even if not protected by the New Zealand Bill of Rights Act [NZBORA]. The NZBORA is not an exhaustive statement of rights (s 28). Article 3(1) of the UNCROC and arts 17, 23 and 24 of the International Covenant on Civil and Political Rights [ICCPR] place the rights and interests of a child as rights and interests of the highest order. The circumstances of this case, which involve the separation of children (who are New Zealand citizens) from their parent and guardian, call for "anxious scrutiny" and the highest intensity of review. Intensity of review of the ss 54 and/or 58 decisions depends upon the whole context ( $R$ (Daly) v Secretary of State for the Home Department, at 548). The whole context includes the best interests of the children who are either about to be removed from their country of citizenship or who are about to have their mother removed from them. The context is not limited by the existence and language of s 47(3) of the Immigration Act 1987. Ye v Minister of Immigration, above n 28, at 111-112. 
standard of review. ${ }^{50}$ For example, Baragwanath $\mathrm{J}$ in Ding $v$ Minister of Immigration advocated a higher level of scrutiny in those immigration cases where a child might be adversely affected: ${ }^{51}$

The Crown is right in its argument that the state interest in immigration control means that it is an area in which courts traditionally show great deference to the policy of the Executive. But to maintain in cases of risk to a citizen child a bare Wednesbury standard of whether the decision-maker took that consideration into account but without awareness of the consequences to the child of an adverse decision, however appropriate for a child who is an alien, is difficult to reconcile with the concurrent Crown obligation of protection of the citizen child. To accept such low level intensity of review is equally difficult to square with the Courts' parens patriae role in relation to citizen children.

However, the elimination of the humanitarian tests in ss 105 and 22 of the 1987 Act as well as the procedure set out in s 171 to quash a deportation order has re-entrenched a more limited standard of review and has potentially severely circumscribed the ability of the courts to review migration decisions, particularly in light of humanitarian and human rights issues.

The effects of these changes, particularly the elimination of the five-pronged humanitarian test in the 2009 Act, are evident in the recent decision by Lang $\mathrm{J}$ in Babulal $v$ Chief Executive Department of Labour. ${ }^{52}$ Lang $\mathrm{J}$ notes that a low Wednesbury standard of review is not new in immigration cases ${ }^{53}$ and observes that s 177 was enacted "as a direct legislative response to ... Ye ... and Huang" and stands for the proposition that an immigration officer is no longer under any obligation "to have regard to the humanitarian grounds" set forth in s $207 .{ }^{54}$ Lang $\mathrm{J}$ continues to hold that the highly deferential Wednesbury reasonableness standard is a sufficient standard of review and explicitly rejects Babulal's request that the Court employ the "hard look" approach due to the probable "severe impact ... [on] Babulal's daughters. ${ }^{55}$ First, Lang J rejects the "hard look" argument because the wording of s 177 gives expansive discretion to the executive. He notes that there is no right to apply for a cancellation order and "no obligation to have regard to the

50 Susan Glazebrook "To the Lighthouse: Judicial Review and Immigration in New Zealand" (paper written for Supreme Court and Federal Court Judges' Conference, Hobart, January 2009).

51 Ding v Minister of Immigration (2006) 25 FRNZ 568 (HC) at [260]. See also Tennent, above n 36, at 298301.

52 Babulal v Chief Executive Department of Labour, above $\mathrm{n} 2$.

53 At [37]. See also Huang v Minister of Immigration, above n 27, at [67] per William Young J:

... the Court should ensure that the best interests of an affected child were genuinely taken into account as a primary consideration but, beyond that, how conflicting considerations are weighted is for the decision maker and not the court unless unreasonableness considerations can be successfully invoked.

54 At [20].

55 At [24]. 
humanitarian grounds" 56 when making a decision (or non-decision) under the section. Further, the immigration officer is under no obligation to provide reasons for not cancelling a deportation order unless the officer "has had regard to New Zealand's international obligations". ${ }^{57}$ However rather than a detailed explanation and analysis of a s 177 decision, this requirement, in Lang J's view, simply calls for "description of the [international] obligations" and a recording of "facts about the personal circumstances of the person subject to the order." ${ }^{58}$ There is no "obligation to give reasons for his or her decision". ${ }^{59}$ Second, the procedure requires that the officer supply a restricted amount of information relating only to the relevant international obligations when making a record of the decision. This enables the barest of Wednesbury scrutiny as to whether the decision-maker considered the appropriate matter in the decisional process: ${ }^{60}$

... where an immigration officer makes a decision that requires him or her to have regard to New

Zealand's international obligations, Parliament intended the record of the decision to contain sufficient

information to allow the decision to be judicially reviewed within a very narrow compass. It accepted

that the court must have sufficient information to be able to determine whether the immigration officer

who made the decision took into account the international obligations relevant to the particular case. The

requirement to record the facts relating to the personal circumstances of the person subject to the

deportation order also provides the court with the ability to determine whether the ultimate decision was

reasonable in a Wednesbury sense, but no more than that.

Third, the failure to mention particular "international obligations" that an officer must have regard to when choosing not to quash the order, as well as the elimination of any humanitarian requirement and five-pronged test in the new statute, limits the ability of the court to undertake a "hard look" review of the decision for material errors of law because there is little law "there" to review. Lang $\mathbf{J}$ acknowledges that an attempt to totally fetter judicial review of an administrative decision must be read down, but that in this case "judicial review ... [is] based on an alleged failure by an immigration officer to have regard to New Zealand's international obligations when reaching his or her decision." 61 However, the salient aspect of the statute is the absence of statutory language that might provide for stricter scrutiny: 62

56 At [20] and [28].

57 At [28].

58 Ibid.

59 At [33].

60 At [36].

61 At [32].

62 At [33]. 
The absence of any requirement to give reasons tells against an expectation by Parliament that the decision will be subject to close scrutiny by the courts, because a lack of reasons will virtually inevitably compromise such an undertaking. As a result, even if the court wished to take a "hard" or "anxious" look at such a decision, it would struggle do so.

The upshot of this is that judicial review of a decision under s 177 is necessarily minimal, regardless of the humanitarian or international obligations arguments put forward. Since Parliament chose not to require a specific justification under s 177 , Lang $\mathrm{J}$ held that there was little necessary documentation to review the decision. For his Honour, the standard immigration officer's consideration record need amount to little more than a docket list of documents containing humanitarian concerns and an incongruous index to "international obligations" to which the official has had regard, concluding with a note that the officer is "not obliged to provide reasons" for his decision upholding the deportation order. Likewise the Court is not required to scrutinise the list, as Lang $\mathbf{J}$ observes that it looks, on balance, to be in order. As a result, Babulal's deportation is reasonable and his appeal dismissed.

The problem with this reasoning from our perspective, however, is how can the Court know, without a record and without resorting to a "hard look" analysis, whether the executive official has had regard to the international obligations referenced by the Court or raised by the petitioner, or whether the relevant obligations have been reasonably interpreted where there is only a (nonexclusive) summary of the factors used in the decision. In effect, the Wednesbury standard under the circumstances leaves little, if any, room for the court to review the efficacy of international obligations in the particular circumstances. The test, as set forth in Babulal simply requires an executive listing of some international obligations and personal circumstances. There is no judicial inquiry, (nor can there be given the paucity of information), into whether or how the obligations or personal circumstances were considered. The resultant decision will always be "reasonable" under Wednesbury since the ultimate test is the mere balancing of probabilities between the public interest in permitting the proposed deportee to remain and the international obligations or humanitarian factors under consideration.

\section{MENTAL HEALTH AND DISABILITY AS A HUMANITARIAN CONCERN AND AN INTERNATIONAL OBLIGATION}

The re-assertion of the Wednesbury standard in Babulal and the continued reliance on minimal levels of judicial scrutiny of executive decisions in migration cases are troubling when considering the potential impact on those deportees who suffer from mental illness, disorder or disability. Mental disabilities include those with mental health problems such as bipolar disease, schizophrenia or emotional impairments that may not affect intellectual function except in some instances, as well 
as those individuals with cognitive disabilities. ${ }^{63} \mathrm{~A}$ "harder look" where the court would inquire into whether the executive has adequately reviewed all the relevant factors and considerations, as well as making a properly reasoned choice, should be required because of the unique context and subject matter. ${ }^{64}$ One aspect of this judicial review should involve consideration of the inability of an individual to understand and appreciate the procedural aspects of the deportation. Another involves the issue of whether (within the context of a deportation process) a mental illness should be considered a "substantive" humanitarian basis for reversing deportation liability. Finally, the low level of review precludes an inquiry into whether the mental illness of a deportee may subject the person to discrimination in his or her home country.

A fundamental requirement from the perspective of the common law is that the potential deportee understands the process by which he or she is to be held liable for deportation. While the authors have been unable to find a case on point it is likely that New Zealand courts will consider a participant's inability to comprehend a legal proceeding to be a violation of a fundamental right of

63 According to the New Zealand Ministry of Health, New Zealand has adopted a phenomenological definition of "mental disorder". Both continual and intermittent manifestations are defined as:

... abnormalities of specific areas of mental functioning (psychopathology) that may be observed. The presence of individual abnormal phenomena does not necessarily indicate a specific illness or diagnosis ...

- rather than one based on a diagnosis, described as:

... an attempt to identify an illness, based not only on the presence of patterns of psychopathological abnormalities, but also on the basis of the cause (aetiology), time course (history) and outcome (prognosis) of the disorder. Diagnosis is relevant to the definition in terms of assessing whether the disorder of mind is of a continuous or intermittent nature (reference omitted).

Guidelines to the Mental Health Compulsory Assessment and Treatment Act 1992 indicate that:

Parliament has deliberately eschewed reference to particular major mental disorders as understood in the psychiatric community. Rather it has set the parameters for establishing the existence or otherwise of a mental disorder according to the presence or absence of observable symptomological indices...

- while maintaining the diagnostic element as relevant to the overall analysis. See for example Re Review Tribunal (RT), 12/4/96, SRT 13/96, cited in Ministry of Health "Guidelines to the Mental Health (Compulsory Assessment and Treatment) Act 1992" (1 April 2000) <www.health.govt.nz>.

64 See Michael Taggart "Proportionality, Deference, Wednesbury" [2008] NZ L Rev 423 for a discussion of the difficulty of applying the "hard look standard" in the New Zealand context. 
fairness or natural justice. ${ }^{65}$ However this issue is not simply procedural in light of s 207 humanitarian tests and the nature of mental illness and disability. As discussed above, what constitutes an exceptional "humanitarian" consideration is often amorphous once outside the Convention relating to the Status of Refugees and the ICESCR, but it is evident that mental disability and the impact such a disability can have on an individual and a family have a humanitarian nexus and should be considered to come within the definition of "humanitarian" under the 2009 Act. Individuals with mental illness are a vulnerable group and can suffer disproportionately more in the deportation process. Mental illness and disability magnify language and cultural barriers, deficiencies in education, anxiety and stress, relative lack of financial resources, the asymmetrical power relationships and the zero-sum nature of the outcome in deportation situations. Because an illness in some sense prevents or detracts from an individual adequately addressing or comprehending these underlying factors, the executive should adequately explore the humanitarian nature of each situation in the first instance and upon review by the courts.

The social stigma and discrimination that often accompanies mental illness and disabilities, similarly requires a more exacting standard of review in light of New Zealand's international obligations. Often these individuals suffer more from the social effects and consequences and the resulting discrimination due to their illness rather than the actual psychological, cognitive and emotional effects of the illness itself. These effects can be magnified under authoritarian regimes or in traditional societies who more openly reflect the deep-seated ambivalence between the humanitarian needs of these individuals and the fear of their difference and potential for criminality. ${ }^{66}$ These international obligations can run in two areas. First, the societal discrimination that an individual suffering from a mental disability may face in their home country should be considered. ${ }^{67}$ Second, the very real potential for discrimination and/or adverse action that an individual faces from State authorities in the country of origin is of particular concern. ${ }^{68}$ There

65 See Cumming $v R$ [2008] NZSC 39, [2010] 2 NZLR 433. While technically not a criminal proceeding it is likely that section 27(1)(a) of the Human Rights Act 1993, which affirms the right of every person to:

... the observance of the principles of natural justice by any tribunal or public authority which has the power to make a determination in respect of that person's rights, obligations, or interests protected or recognised by law ...

- would extend the principle in light of the fundamental interests at stake in removal proceedings.

66 TW Harding "Human rights law in the field of mental health: a critical review" (2000) 101 Acta Psychiatrica Scandinavia 24 at 24-25.

67 For a general discussion on stigma in the mental health context, see Peter Byrne "Stigma of mental illness and ways of diminishing it" (2000) 6 Advances in Psychiatric Treatment 65.

68 See for example Human Rights Watch Once You Enter, You Never Leave: Deinstitutionalization of Persons with Intellectual or Mental Disabilities in Croatia (September 2010). The report writes of the high rates of institutionalisation for individuals (including children) with mental and intellectual disabilities. Croatia and New Zealand have nearly identical population sizes (roughly 4.2 million people). Croatia incarcerated approximately 4,000 adults with mental illness in 2008 compared to 1,650 adults (including 1,520 
continue to be serious problems regarding the classification, placement and treatment of many individuals suffering from mental health problems; including long periods of isolation in unclean unsanitary spaces, lack of adequate nutrition, care and appropriate medical treatment as well as severe maltreatment. ${ }^{69}$

Recognition of these discriminatory effects can be observed in the range of possible international obligations germane to the proper determination of humanitarian concerns for a potential deportee with mental illness. The immigration officer, IPT and court should have regard to several additional treaties specifically ratified by New Zealand, including the Convention on the Rights of Persons with Disabilities (CRPD) (ratified in 2008); the ICESCR (ratified in 1978); the ICCPR (ratified in 1978); and the Convention on the Elimination of All Forms of Discrimination Against Women (CEDAW) (ratified in 1985), in addition to UNCROC and the Convention on Refugees. ${ }^{70}$ Beyond formal ratified obligations there are other international instruments which should also be included or offered by an advocate for an individual with mental illness concerns to the officer, tribunal or court for consideration in light of the Act's inclusion of international obligations. These instruments include: CEDAW (art 5(e)(iv)); the Declaration on the Rights of Mentally Retarded [sic] Persons (1971); the Declaration on the Rights of Disabled People (1975); the Principles for the Protection of Persons with Mental Illness and the Improvement of Mental Health Care (1991) ${ }^{71}$ and the Standard Rules for the Equalisation of Opportunities for Persons with Disabilities (1993). ${ }^{72}$

compulsory inpatient and 130 mixed inpatient and community compulsory treatment) in New Zealand. See Ministry of Health Office of the Director of Mental Health: Annual Report 2010 (October 2011) at 19.

69 European Court of Human Rights "Fact Sheet - Mental Health" (February 2011) <www.echr.coe.int>. See for example Arman Vardanyan, Director of the Mental Disability Advocacy Center in Budapest "Human Rights and Mental Disability" (OSI Public Health Seminar, Budapest, 23 January 2003).

70 United Nations Convention on the Rights of Persons with Disabilities 2515 UNTS 3 (opened for signature 30 March 2007, entered into force 3 May 2008); ICESCR, above n 22; ICCPR 999 UNTS 171 (opened for signature 16 December 1966, entered into force 23 March 1976); International Convention on the Elimination of All Forms of Discrimination Against Women 1259 UNTS 13 (opened for signature 1 March 1980, entered into force 3 September 1981); UNCROC, above n 22; and Convention relating to the Status of Refugees, above $\mathrm{n} 22$.

71 For instance, the United Nations Principles for the Protection of Persons with Mental Illness and for the Improvement of Mental Health Care GA Res 46/119, A/Res/46/119 (1991) at [4] directs:

There shall be no discrimination on the grounds of mental illness. "Discrimination" means any distinction, exclusion or preference that has the effect of nullifying or impairing equal enjoyment of rights. Special measures solely to protect the rights, or secure the advancement, of persons with mental illness shall not be deemed to be discriminatory. Discrimination does not include any distinction, exclusion or preference undertaken in accordance with the provisions of these Principles and necessary to protect the human rights of a person with a mental illness or of other individuals [Principle 1(4)]; [and] 
The Immigration Operations Manual in effect at the time of writing generally addresses the matter of "international obligations"73 and indicates that a "protected person" may be deported to a third country (the privilege of remaining in New Zealand is implied) but not to the country of origin where "cruel treatment" is believed to confront the individual upon his or her return. ${ }^{74}$ Under the ICCPR, an individual must be recognised as "protected" if there are "substantial grounds for believing that he or she would be in danger of being subjected to arbitrary deprivation of life or

Every person with a mental illness shall have the right to exercise all civil, political, economic, social and cultural rights as recognized in the Universal Declaration of Human Rights, the International Covenant on Economic, Social and Cultural Rights, the International Covenant on Civil and Political Rights, and in other relevant instruments, such as the Declaration on the Rights of Disabled Persons and the Body of Principles for the Protection of All Persons under Any Form of Detention or Imprisonment [Principle 1(5)].

72 International Convention on the Elimination of All Forms of Discrimination against Women, above $\mathrm{n} 70$; United Nations Declaration on the Rights of Mentally Retarded Persons GA Res 2856, XXVI (1971); United Nations Declaration on the Rights of Disabled Persons GA Res 3447, XXX (1975); the United Nations Principles for the Protection of Persons with Mental Illness and the Improvement of Mental Health Care GA Res 46/119, A/Res/46/119 (1991); and the Standard Rules for the Equalisation of Opportunities for Persons with Disabilities GA Res 48/96, A/Res/48/96 (1993).

73 Immigration New Zealand "Immigration Operations Manual: Temporary Entry" (30 July 2012) <www.immigration.govt.nz> at Part E10.1. The Manual defines one such area of "international obligation" as the United Nations Educational Scientific and Cultural Organization [UNESCO] Convention on the Protection and Promotion of the Diversity of Cultural Expressions. While this provision notes that New Zealand intends for this obligation to apply only on decisions on admission to New Zealand, it notes in pertinent part that:

d. To give effect to this facilitation, when considering applications for temporary entry to New Zealand from artists and other cultural professionals and practitioners, immigration officers should have regard to New Zealand's obligation under the convention and should:

i. consider expediting applications on a case-by-case basis; and/or

ii. take into consideration, as part of the standard decision-making process, any supporting information submitted by the Ministry for Culture and Heritage on the applicant's behalf (for example, if the applicant is part of a formal exchange programme organised by the New Zealand Government).

e. These measures will not influence INZ's ability to determine the intentions of an applicant, or override any applicable character, health, or any other requirements in immigration instructions.

It is telling that for temporary cultural visits, more guidance is given to the Immigration Officer and a more vigorous interrogation of the circumstances is suggested than in the case of deporting an individual with a mental illness back into a context that would likely result in the individual being exposed to abject discrimination.

74 Immigration New Zealand "Immigration Operations Manual: Compliance" (30 July 2012) <www.immigration.govt.nz> at Part D2.20. See also Immigration Act 2009, ss 164 and 166. 
cruel treatment if deported from New Zealand". ${ }^{75}$ Interestingly, this section does not require "certainty" of discrimination but only evidence that there is the possibility of being subjected to cruel treatment. The: ${ }^{76}$

... refugee and protection officer concerned must take into account all relevant considerations, including, if applicable, the existence in the country concerned of a consistent pattern of gross, flagrant, or mass violations of human rights.

It is following this instruction that certain limitations are added to the eligibility of prospective protected persons, including: ${ }^{77}$

... the impact on the person of the inability of a country to provide health or medical care, or health or medical care of a particular type or quality, is not to be treated as arbitrary deprivation of life or cruel treatment.

Cruel treatment is defined as cruel, inhuman, or degrading treatment or punishment.

The United Nations has offered additional guidance on the nature of several of New Zealand's international obligations in the area of disability (including mental illness): ${ }^{78}$

The Universal Declaration of Human Rights, the International Covenant on Economic, Social and Cultural Rights, and the International Covenant on Civil and Political Rights together form what is known as the International Bill of Human Rights. These three documents together recognize the civil, cultural, economic, political and social rights that are inalienable to every human being; thus, the International Bill of Human Rights recognizes and protects the rights of persons with disabilities, even if those persons are not explicitly mentioned.

Further, New Zealand's Human Rights Commission has described the nature of the obligations arising under the ICCPR as: ${ }^{79}$

... absolute and to take effect as soon as a State ratifies the Covenant. The rights apply equally and without discrimination. The obligations to ensure equality and non-discrimination are described as nonderogable. That is, once a State ratifies the covenant it cannot deviate from them under any circumstances.

Limitations include only those circumstances constituting an existential threat to the nation State or to "protect the rights or reputations of others, in situations of public emergency, and if they are

75 Immigration Act 2009, s 131(1).

76 Ibid, s 131(3).

77 Ibid, s 131(5)(b) (emphasis added).

78 United Nations "Chapter Two: The Convention in detail" United Nations Enable <www.un.org>.

79 Human Rights Commission "Chapter 2: The international human rights framework" <www.hrc.co.nz>. 
prescribed by law." ${ }^{80}$ Neither of these exceptions is implicated in the mental health and disability considerations.

The interaction of the international and domestic law in the Act creates a hierarchy that affects the manner in which humanitarian considerations are taken into account in deportation cases. Refugees and protected persons are afforded the most protection. Correspondingly, they are held to exacting evidentiary test standards to determine whether the applicant for either category meets the requisite test. Failing that, an individual facing deportation might resort to the broader argument of cancellation of a deportation order on humanitarian grounds. The additional burden under this analysis is the inclusion of the balancing test of particular, specific and "exceptional" reasons that when considered in light of the community interest in deporting the individual, outweigh that community interest. For instance, an application for consideration as a protected person might be lodged when either the individual or advocate becomes aware of the mental health diagnosis and if there is a reasonable suspicion that the country of origin or of habitual residence might fit the criteria warranting the protection status application. At the same time, the appeal on humanitarian grounds might be lodged with a request to stay the deportation and the appellate proceedings before the IPT, until such time as the protected person inquiry has been made and a decision reached. There are seemingly important procedural differences in both avenues remaining in New Zealand. The humanitarian appeal is one of last resort and permits admission of a wide range of evidence to strike the proper balance between humanitarian factors, many of which might overlap with evidence in the protected person proceeding. However in the former, it is this evidence that is balanced against the public interest in allowing the individual to stay that is at issue. In the protected person analysis, inquiry is made to ensure the applicant is not a war criminal, for instance; no other inquiry is made as to the applicant's character as it is not relevant to their status as a protected person. In contrast, the humanitarian appeal is the last ditch effort to remain in New Zealand. The IPT takes into account all manner of evidence relating to the specific grounds for humanitarian consideration (including "victim statements" where a crime has been committed) as grounds for deportation in order to decide whether, on the balance of probabilities, the individual should be permitted to remain in New Zealand, despite the determination of the immigration officer.

The idea that domestic human rights commitments, incorporated and unincorporated international human rights commitments and the broader understanding of the discrimination and vulnerability of deportees with mental illness or disability merit the executive taking a harder look at the particular circumstances and the courts eschewing a simple Wednesbury analysis, nevertheless fails to address some underlying issues. The reincorporation of legal standards for what constitutes "humanitarian" - such as those standards used in s 105 of the Immigration Act 1987 - and a more cogent judicial determination of the impact of incorporated and unincorporated treaty obligations to assist judicial review, would be desirable. However, such judicial actions will not eliminate 
enduring tension between elements of natural justice and the international law principle of defining one's political community and controlling a nation's borders. Where an individual commits a criminal act the criminal justice system has been established to punish and rehabilitate offenders so that by the time of their release, they are deemed suitably chastised and able to re-enter society. In other words, where a criminal offender has been tried, convicted and sentenced, the criminal punitive portion of his or her debt to society has been adequately addressed under law. In the immigration context, where an individual commits a criminal act they are not only responsible for violating the specific criminal statute but also for violating a term of their agreement under their visa or permit to refrain from such acts. Deportation is of course the easiest and perhaps most costeffective manner of dealing with the immediate problem of having an immigrant ex-convict in our midst; the "problem" is merely repatriated to become the matter of concern for the nation of birth or nationality. On the other extreme, allowing a convicted alien to remain carries the risk of recidivism and the undermining of the coercive tool of the State to ensure compliance with immigration law.

In contrast to this zero-sum game, however, middle-range and more focused tribunals have been developed across other developed nations. These include drug courts, mental health courts, diversion programs and community courts, which are constructed in a manner that involves regular reporting to probation departments, community partners or directly to the court. ${ }^{81}$ These are institutions that have individuals as their focus and beyond them, the affected communities. Mental health factors, in particular, pose additional burdens on the applicant such as lack of adequate and effective access to counsel, challenges to effective communication with family, advocates and the Tribunal, and difficulty in developing a trusting open relationship with one's advocate. Those suffering from mental illness are likely to have greater difficulty in preparing for their deportation case. Mentally ill clients' cases are particularly vulnerable not only because clients struggle to comprehend what is occurring, but also because of complications with their medications. Because of these factors, immigration officials and IPT members need professional assistance in determining the nature and extent of the mental illness, a process for appointing guardians ad litem, funds for the appointment of counsel to represent respondents, and the discretion to release the person from detention and/or to order appropriate medical care for the respondent. When the mental illness is directly related to the ground for removal, the immigration judge needs the discretion to cancel the proceedings - with or without prejudice - or to hold the matter in abeyance while the respondent is

81 For instance, Bill Hing writes about the United States' [US] deportation experiences to conclude that immigration judges (their equivalent of Immigration Protection Tribunal decision-makers in New Zealand) need special options when a respondent is suffering from a mental illness beyond cancellation of removal. In such cases, US immigration judges are instructed to consider the following factors: family ties to the US; length of residence in the US; evidence of hardship to the respondent and family if deportation occurs; service in the US military; rehabilitation; and evidence of good character. These are strikingly similar considerations to the old s 105 tests for cancellation of deportation orders on humanitarian grounds now removed from the new Act. See Bill Ong Hing "Systemic Failure: Mental Illness, Detention and Deportation" (2010) 16 U C Davis J Intl L \& Poly 341. 
able to avail himself or herself of appropriate care. From this perspective, the challenge is not so much in questioning a State's right or inherent power to define entry requirements for its political community but rather to ensure that those categories, standards and processes reflect New Zealand's values with regard to identity. The discriminatory aim of the immigration laws might have legitimate State interests in mind, but once admitted into the nation, one's immigration status can have a profound impact on access to justice.

\section{CONCLUSION}

Immigration law is an inherently discriminatory aspect of public law and is one of the few remaining areas where the State can, under the guise of State sovereignty, enjoy almost unbridled power to favour individuals for admission to (or exclusion from) the political and social community. With the safeguards meant to screen out individuals who are unwell or who might otherwise not meaningfully contribute to the society already in place, the question of whether these migrants might be owed any further consideration of their particular circumstances before they are merely subjected to, as Peutz has observed, a state of "reversed refugee-ness" where "instead of being forced to leave one's nominal home, deportees are forcibly repatriated", ${ }^{82}$ might be worth asking.

Several of the changes in the 2009 Act, however, reflect a parliamentary intention to restrict judicial review and latitude that would require the executive and the courts to undertake a more exacting consideration of exculpatory circumstances in the deportation process where mental illness and disability are involved. The Act consolidates the previously separate processes of deportation and removal into a new deportation process, consolidating not only the processes available to appellants of an adverse immigration order but also the number of competent administrative or quasi-judicial agencies empowered to consider these appeals to the IPT. In addition, one of the central safeguards employed by the courts from the Immigration Act 1987, the five-pronged humanitarian factor test found in s 105, has been completely omitted from the 2009 Act.

In order to be true to domestic commitments to have regard to human rights and international obligations - both incorporated and unincorporated, especially in the mental health and illness context - the critical issue is not simply the availability or absence of a mental health treatment in the home country or a focus on the potential deportee's crimes. There must instead be a thorough examination of the particular effects on the individual and an inquiry into the home State's mental health policy and societal norms. This is crucial to ensuring the absence of discrimination on the basis of the deportee's mental health diagnosis upon repatriation. In order to enable a thorough consideration of the applicant's circumstances, it is critical that the immigration officer, IPT and the courts undertake a detailed review of the particular circumstances of the deportation to first ensure that the individual is not entitled to protected person status and, failing that, that a humanitarian cancellation of the deportation order should not be granted in light of the likely adverse treatment

82 Nathalie Peutz "Embarking on an Anthropology of Removal" (2006) 47 Current Anthropology 218 at 218. 
that activates the ICCPR. The courts should take a "hard look" at any matter raising these concerns rather than using the Wednesbury reasonableness test, since such instances are often very fact specific and require more information in order to ensure that New Zealand is meeting its international obligations. This approach is preferable to merely gleaning information from the very general summary provided by an immigration officer who is not obliged to report a justification for his or her decision.

In the long term, however, if New Zealand wishes to continue to pride itself as a progressive advocate for human rights and humanitarian concerns then it should choose to lead the way in applying international human rights protections to individuals, allowing them to avoid deportation where their mental health or other disability was either a critical element of their underlying offence, or where the deportee is likely to face discrimination in his or her home country on the basis of their mental illness or disability status. Further factors should include where the individual has been a long term New Zealand resident (especially those having arrived in childhood), who while having fully undergone the enculturation process here in New Zealand, may have faltered in the face of enormous social and economic obstacles. These are areas that other aspects of our public policy have long recognised and have long grappled with solving or ameliorating. Our domestic human rights commitments as well as our international human rights obligations should be cherished as embodying domestic social, as well as legal, values. 